\title{
TEACHING BY ALPHABET POEM IN ENHANCING STUDENT'S LEARNING STYLE
}

\author{
Muhammad Dalimunte ${ }^{1}$ \\ Universitas Islam Negeri Sumatera Utara, Medan, Indonesia \\ muhammaddalimunte@uinsu.ac.id \\ Sholihatul Hamidah Daulay ${ }^{2}$ \\ Universitas Islam Negeri Sumatera Utara, Medan, Indonesia \\ sholihatulhamidah@uinsu.ac.id \\ Atika Winari Putri ${ }^{3}$ \\ Universitas Islam Negeri Sumatera Utara, Medan, Indonesia \\ atikawinariputri@uinsu.ac.id
}

\begin{abstract}
The aim of this paper is to determine the Alphabet Poem in teaching English. This paper investigates how Alphabet Poem knowledge can help to teach English in English Language Teaching (ELT). The author will conduct a literature review method. The purpose of this paper was to study how alphabet poem can enhancing student's learning style. The method by using library research and a philosophical or pedagogical approach. The results showed that the role of alphabet poem in teaching English is suitable for learning styles (visual, auditory, and kinesthetic). English students will benefit from the knowledge of alphabet poems and how to teach teaching materials in three different learning styles. The applied linguistic content helps language learners better understand alphabet poems in ELT. The study draws the attention of teachers to be more concerned with the communication condition of students by the creative poem and to the fact that teachers cannot act as expected unless they are each of their learning styles. The teacher brings and teaches the alphabet poem to the students so the students who receive it will also imitate how to make the alphabet poem again so that through learning English it becomes a lesson that is liked by students and students can fluently in English.
\end{abstract}

Keyword: Learning Style, Alphabet Poems, English Language Teaching.

\section{INTRODUCTION}

Matsuda (2017) defines English as an international language as a function that English performs in international, multilingual contexts, to which each speaker brings a variety of English that they are most familiar with, along with their own cultural frames of reference, and employs various strategies to communicate effectively. Mastering English is one of the ways to achieve dreams. All fields of work require English. The requirement to have proficiency in English is something that must be met in the requirements. Some people who are aware of the importance of having the ability to the expertise of English, learn English from an early age. Parents teach English to children, provide educational facilities to learn English. Children go to schools that have the advantage of practicing English. After school, children are fun to go to English courses. Parents provide support facilities for children to get used to learning English at home. Even parents have started to get used to speaking English to children. 
Change all the circle of children with English language culture from childhood.

The awareness of the importance of English causes English teachers to have many methods to teach students' English skills. Adjusted to the interests of the student, the ability to receive English lessons, and the period to master English. The process of learning English to get students interested should vary in the method. Each student learns a variety of methods so that learning becomes comfortable and learning objectives can be achieved. Students with visual, auditory, or kinesthetic learning styles have each method that is compatible with one another.

In addition, everyone has a favored learning style. Knowing and understanding our learning style assists us with learning all the more successfully. This is especially valid for individuals with learning hardships as a result of their various methods of learning. (Eleni Andreou \& Filippos Vlachos, 2013). Learning style information obtained by Visual Auditory and Kinaesthetic assessment proved to be useful for students with learning difficulties, when built into multisensory learning plans to enhance language acquisition and reading ability.

The teacher does not only deliver the material after it is finished, but the teacher is required to deliver the learning material and the students master the material presented. So a student's learning style is an important concern for teachers in applying English learning methods. Alphabet Poem is one of the methods used by a teacher to apply it to students. This paper will discuss whether this method is suitable for use by all student learning style methods or not. Researchers are interested in discussing this theme to see how a method works well in the learning process.

\section{LITERATURE REVIEW \\ 1.1 Learning Style}

Teaching is not just conveying subject matter but requires creative methods that attract students to receive learning fun and understand lessons very easily. However, in the teaching process, some teachers have difficulty delivering material to students, especially English teachers. Where not all students are interested in English. In the teaching and learning process, the teacher will meet students with different learning styles. There are those who act like to talk, and some are quiet and passive, and there are even students who can't be silent and easily make a scene. The teacher will not be able to force the student according to what the teacher wants. All of them have differences from one another. Because the ability of students to understand learning depends on their learning style. According to DePorter and Hernacki (2003: 112), learning styles are a combination of absorbing, organizing, and processing information. These learning styles include Visual, Auditory, Kinesthetic.

\section{A. Visual}

Students with visual learning styles tend to learn through the sense of sight. Learn faster to understand if through visual displays such as pictures, videos, and diagrams. Even in the learning process, students will see the attitudes, movements, and lips of the teacher who are explaining the lesson. Difficulty if you receive learning through oral. Hamzah (2008: 181) further explains that the characteristics that are typical for student who use visual learning styles are:
a. The need to see something (information/lesson) visually to know or understand it;
b. Has a strong sensitivity to color;
c. Have sufficient understanding of artistic issues;
d. Having difficulties in direct dialogue;
e. Too reactive to sound; 
f. Difficulty following verbal recommendations;

g. Often misinterpret words or words.

\section{B. Auditory}

Students with auditory learning styles tend to learn through the sense of hearing. Learn faster to understand if absorbed through hearing such as imitating tone, time, and color. Even in the learning process, students will quickly listen to what the teacher says or is conveyed by discussion partners in the group. Difficulty if receiving learning through writing. There are several characteristics of student base on (Hamzah, 2008: 182) who have this audio learning style:
a. Information can only be absorbed through hearing;
b. Having difficulty absorbing
information in written form directly;
c. Having difficulty writing or reading.

\section{Kinesthetic}

Students with kinesthetic learning styles tend to learn through moving, monitoring, and doing things. Learn faster to understand if the limbs move, can not sit pretty. Always want to move like practice, games, and physical activity. For student with this kinesthetic learning style according to (Hamzah, 2008: 183) there are several characteristics, namely:

a. They tend to put their hands as the main means of receiving information in order to keep on remembering them;

b. Only by holding can absorb the information and without having to read the explanation;

c. In learning, they tend not to be able to / endure sitting too long to listen to lessons;

d. Prefer if learning is accompanied by physical activity;

e. Having the ability to coordinate a team and the ability to control body movements (athletic ability).
The variety of student learning styles so that teachers can provide integral learning in facilitating students in learning because the three learning styles also have a significant effect on their learning achievement (Bire, Geradus, \& Bire, 2014). The learning process tends to use one learning medium and it is only in accordance with one student learning style. That is what causes students to have difficulty understanding if their learning style tends to be incompatible with the teacher's teaching method. The teacher must choose the right method that can be used by different learning styles so that students can understand it very easily and lead to a fun learning process.

\subsection{English Language}

English language development is a basic ability that must be possessed by every child because it is a medium of communication in the community environment. Meanwhile, students interact a lot with the teacher during the teaching and learning process, especially learning English. According to (Suyanto, 2008) the importance of the role of English in Indonesia is a foreign language. In line with the opinion (Gusrayani, 2014) states that English is an international language which is also a language that is widely taught and controlled by many developed countries in the world. Syafei (2016) states that Introducing English to Young Learners is guiding and facilitating young learners ages 5-12 years old.

English was introduced to The United Kingdom about 1500 years ago by invaders from the North Sea coast of the Continent. Thus, these invaders are known as Anglo-Saxons. He added that they were initially illiterate, but within a few centuries of settling in England, they had mastered the use of writing and then they began. Write down all sorts of things in their English literature. English as international languages have changed throughout its history. Khansir and Tajeri 
(2015; p.66) mention that "language changes throughout its existence - new words are introduced, old words are no longer used, there is a shift in meaning and changes in pronunciation. English is no exception."

Khansir (2013) argues that the aim of teaching English language is to make learners as effective language users. $\mathrm{He}$ mentioned general goals teaching English as follows:

a. In listening, the general purpose of teaching English is to enable learners understand English when it is spoken at normal conversational speed;

b. In speaking, the general purpose of teaching English is to enable students to speak English with fluency, accuracy and compatibility;

c. In reading, the general purpose of teaching English is to enable students to read English with understanding at a reasonable pace;

d. In writing, the general purpose of teaching English is to enable students to write English neatly and correctly.

\subsection{Alphabet Poem}

\section{A. A Brief History}

An article describing a brief history of alphabet poetry. The article The Economist was written on 23 Oct 1993 by NYR Indictor in Chappaqua, New York

\section{a. Hebrew Biblical Alphabet Poetry}

Hebrew alphabet poems are variously structured, but all are acrostic. 'The Hebrew alphabet, has twenty-two letters whose order has remained largely unchanged since antiquity. Most of the alphabet poems contain twenty-two verses or a multiple thereof.

b. Latin Alphabetic Hymns

Perforce Latin hymns are generally solemn in nature, but the playfulness of the alphabetic structure intrudes slightly in these works. We see altered spellings to provide words for the more difficult letters ("Karus" for "carus") and Greek and even
Hebrew phrases are sometimes borrowed by the poet desperate for an X- or Z-word. Sometimes extensive alliteration is employed as well, reinforcing the alphabetic structure of the hymn.

c. Rune Poems

Rune poems are also found in Old Icelandic (earliest manuscript VIIth I 134 century), and Old Norse (earliest manuscript XIIth century, now destroyed).

d. Vernacular Alphabet Poems

Sometime before the advent of the printing press, as authors were making the transition from Latin to their native European languages, it was inevitable that someone should think to write alphabet poems in English, French and other vernaculars. The earliest English alphabet poems (Roman. rather than Runic) date from no later than the XIVth century. and the earliest one of known authorship is by Geoffrey Chaucer. His poem, which is usually untitled or simply called "An ABC".

e. Modern Early Alphabet Poetry

Until the XVIIIth century, most books for children were on religious themes, and it is natural that when alphabet poetry begins to figure widely in children's literature, religious themes continue to dominate (quite a few are still being published, but they are far outnumbered by secular ones). XIX and XXth century alphabet poetry exhibits a wide variety of styles. Edward Lear wrote a round dozen droll alphabets, pioneering in the field of alphabetic silliness. Younger authors have in recent decades changed the nature of poetry, and our definition of it has become more inclusive. Varieties of alphabet poetry have consequently increased.

\section{B. Alphabet Poems}

Students like a fun learning method so that they can master English easily. one of the methods uses Alphabet poem. Alphabet poem is poetry that uses all 26 letters in the alphabet. Write with a few conditions: 
a. Write all the letters of the alphabet on the left side of the paper or book.

b. Each letter, write down a phrase that focuses on one topic. Or, you can write narrative poetry in Alphabet Poem format.

c. Students must be creative and stay focused on the topic.

d. Determine the topic or theme to be told in the poem.

e. The first word of each phrase or sentence must begin with the letter of the alphabet on the line

f. Write sequentially from letter $A$ to letter $\mathrm{Z}$.

g. Write in a creative and interesting way. You can add painting images and colors to support a more attractive poetry display.

\section{Example of Alphabet Poem From World War Two}

This thought-provoking alphabet/list poem is filled with emotional realities which the city children of world war two were faced with during evacuation, and is all told in rhymeand rhythm, with lots of alliteration for effect. It has been selected for use by museums, exhibitions, and publishers as an example of world war poetry for children.

Air raid shelters, damp and black Bombs exploding, back to back Children crying, adults too "Down the cellar-after you" Evacuees on the train Farewells said in pouring rain Gone to live in some strange place Hoping for a friendly face. In the city, parents wait Just to hear of their child's fate Knowing that they have arrived Leaves them thankful they've survived Memories now not theirs to make No hugs or kisses; birthday cake. Only painful loss is theirs Parting sorrow, daily prayers. Quick to jar them from their pity: Raids repeating on the city. Sirens screeching, chaos calls, Thunderous noise as buildings fall.
Underground: imaginations, Violent earth reverberations. Why oh Why? Despair abounds. eXit all, as fear resounds Yesterday for now is gone Zeal for life and peace lives on.

\section{RESEARCH METHOD}

This study uses library research, which is a series of research by collecting library data or collected based on various sources of information (books, encyclopedias, scientific journals, newspapers, magazines, and documents). Library research to analyze questions that will be analyzed based on the questions that have been formulated. This research is a descriptive analysis, namely an explanation of the data that has been obtained, then an explanation of the explanation is given so that this research is easily understood by readers and can take the knowledge therein.

The approach used in this research is a philosophical and pedagogical approach. The philosophical approach is an approach taken to reason and compile data systematically based on a certain point of view (in this case the point of view used is the historical point of view in learning). Meanwhile, the pedagogical approach is an approach to explain data in more detail by using the theory of locating historical genetic moments in learning.

\section{RESULTS AND DISCUSSION 4.1 Principles in teaching poetry}

Etymologically, the meaning of poetry is called poem or poetry, which means a work of art that is entertaining and has a function (Barnet, 2003). Poetry means creating entertaining works of art because writing poetry means creating a world.

Before training students to write poetry, teachers should pay attention to the principles of learning, especially for children or students. Brown (2001) said that there are several things that should be considered by teachers first. Among them 
are students will learn if they are actively involved, students will be more motivated to learn if they can interact with other people, for example, friends or teachers, teachers should create a comfortable and peaceful atmosphere so that students feel free and free from feelings of anxiety, students should be encouraged to find something and trained to write, poetry writing skills will be successful if the skills are divided into sub-skills and sorted according to the level of difficulty. These learning principles can be applied in teaching poetry. Poetry is an expression of thoughts, ideas, and expressions of a poet. Writing poetry requires creative skills. Creative expressions in poetry are not easy to teach. Often teachers feel that they must be able to balance students' freedom of expression with the demands of the elements contained in poetry. For this reason, there are several principles that must be considered by the teacher.

\subsection{Alphabet poems are suitable for three learning styles}

The alphabet poem can be used in all three learning styles (Visual, Auditory, and Kinesthetic) in different ways according to the students' learning style. Alphabets poems that is suitable for visual learning styles (Learning by sight) are in the form of pictures, graphics, illustrations, slides, and colorful writing. So that the teacher wrote an interesting alphabet poem with colorful pictures and writing. Besides that, students with a visual learning style will also pay attention to their gestures or body language when the teacher explains. Indirectly, the teacher can become a teaching medium for students with a visual learning style. They sometimes absorb information by looking at the other person. Therefore the teacher must also maintain eye contact while teaching alphabet poems.

Alphabets poems that are suitable for auditory learning styles (learning by listening) are in the form of videos, voice recordings, and storytelling patterns with sounds, rhythms, and tones. So that the teacher prepares the sound from the CD or video about the alphabet poem so that students are interested in learning about the alphabet poem material. The alphabet poem suitable for the kinesthetic learning style (learning by moving, working, and touching) is a teaching aid. Or indirectly, students can become teaching media by doing physical movements to give examples of vocabulary from the alphabet poem.

\section{CONCLUSION}

Alphabet Poem is a learning method in English that can be adapted to the learning style of each student. The teacher can create creations on how to teach alphabet poems in a way that is interesting and easy for students to understand. So that they like English learners and the goals of teaching and learning are achieved, what is conveyed by the teacher becomes new knowledge for students. The teacher must also master the learning styles of each student. The alphabet poem is suitable for teaching elementary or junior high school students. The teacher brings and teaches the alphabet poem to the students so the students who receive it will also imitate how to make the alphabet poem again so that through learning English it becomes a lesson that is liked by students and students can fluently in English.

\section{REFERENCES}

Andreou, E., \& Vlachos, F. 2013. Learning Styles of Typical Readers and Dyslexic Adolescents. Journal: Visual Literacy

Barnet, Sylvian. 2003. Short Guide to Writing about Literature. NewYork: Longman.

Bire, A. L., Geradus, U., \& Bire, J. 2014. Pengaruh Gaya Belajar Visual, Auditorial, dan Kinestetik Terhadap Prestasi Belajar Siswa.

Brown, H. Doughlas. 2001. Teaching by Principles. San Fransico: Longman. 
De Porter, Bobbi. 2003. Quantum Learning Membiasakan Belajar Nyaman dan Menyenangkan. Bandung: Kaifa

Gusrayani. 2014. Teaching English to Young Learners (Sebuah Telaah Konsep Mengajar Bahasa Inggris Kepada Anakanak). Bandung: UPI Press.

Hakim, Lystiana Nurhayat. Socio-Affective Strategies in Enhancing Students, Speaking Motivation. Jurnal Basis, [S.1.], v. 6, n. 1, p. 125-133, apr. 2019. ISSN 2527-8835. Available at: <http://ejournal.upbatam.ac.id/index.php/ basis/article/view/1051>. Date accessed: 20 sep. 2021. doi: https://doi.org/10.33884/basisupb.v6i 1.1051.

Multilingual Matters. Lee, J. S., \& Lee, K. (2018). Perceptions of English as an international language by Korean English-major and non-English-major students. Jurnal Basis, v.20, p. n. 2, p. 186-189, jul. 2017. ISBN 978-1-78309701-2. Available at: < https://www.tandfonline.com/doi/full/10. 1080/13488678.2017.1345556>. Date accessed: 21 sep.2021. doi: https://doi.org/10.1080/13488678.2017.13 45556.

Ridianto, Ridianto. Students' Perception on Language Style Used By English Lecturers in The Classroom. Jurnal Basis, [S.1.], v. 5, n. 1, p. 39-44, apr. 2018. ISSN 2527-8835. Available at: <http://ejournal.upbatam.ac.id/index.php/ basis/article/view/457>. Date accessed: 20 sep. 2021. doi: https://doi.org/10.33884/basisupb.v5i 1.457.

Romaine, Suzanne. 1994. Language in Society. Oxford: Oxford University Press

Suyanto, K. 2008. English For Young Learners. Jakarta: PT Bumi Aksara.

Syafei. 2016. Teaching English to Indonesian Young Learners (Edisi Pertama). Jakarta: Kencana.

Trudgill, Peter. 1983. Sociolinguistics: An Introduction to Language and Society.London: Penguin.

Uno, Hamzah B. 2008. Orientasi Baru Dalam Psikologi Pembelajaran. Jakarta: Bumi Aksara.

Utami, Valisneria. EFL Learner's Pronunciation Problems: A Phonological
Analysis. Jurnal Basis, [S.1.], v. 7, n. 1, p. 171-184, apr. 2020. ISSN 2527-8835. Available at: $<$ http://ejournal.upbatam.ac.id/index.php/ basis/article/view/1788>. Date accessed: 20 sep. 2021. doi: https://doi.org/10.33884/basisupb.v7i 1.1788 
